\title{
PERANCANGAN ULANG TATA LETAK FASILITAS MENGGUNAKAN METODE MULTI-OBJECTIVE FUNCTION DAN SIMULASI ARENA
}

\author{
Rizaldi Syargawi ${ }^{1}$, Deny Andesta ${ }^{2}$, Dzakiyah Widyaningrum ${ }^{3}$ \\ ${ }^{1}$ Mahasiswa Teknik Industri, Fakultas Teknik, Universitas Muhammadiyah Gresik \\ ${ }^{2,3}$ Dosen Teknik Industri, Fakultas Teknik, Universitas Muhammadiyah Gresik Jl. Sumatera No. 101 \\ GKB-Gresik 61121, Jawa Timur, Indonesia \\ Email : rizaldisyargawi@gmail.com
}

\begin{abstract}
ABSTRAK
PT. Sumber Urip Sejati adalah perusahaan yang bergerak di bidang karoseri dan juga distributor velg. Dalam produksi trailer ada beberapa tahap untuk menghasilkan sebuah produk trailer, yaitu tahap perakitan, tahap pengecatan dan tahap perakhir adalah tahap pemasangan aksesoris. Tata letak PT. Sumber Urip Sejati memiliki kekurangan yaitu layout yang tidak menguntungkun dalam segi material handling.

Pada metode MOF (Multi_Objective Function) pengatuiran site layout harus mempunyai data berupa jarak dan juga frekuensi penggunaan fasilitas untuk melakukan perhitungan demi mendapatkan site layout yang maksimal. Pada metode MOF terdapat 2 variabel yang biasanya digunakan pada metode ini yaitu Travel Distance (TD) dan Safety Index (SI). Pada penelitian ini juga meggunakan Arena untuk mengetahui performa layout awal dan layout usulan.

Dari hasil penelitian bahwa dalam penelitian ini terjadi pengurangan jarak perpindahan material dari layout awal sebesar 47786 meter menjadi 44066 meter pada layout usulan dan juga pada layout usulan terjadi penurunan nilai Safety Index dari layout awal sebesar 1649,9 menjadi 1626,4.

Kata kunci: Tata Letak, MOF, Arena
\end{abstract}

\section{PENDAHULUAN}

\subsection{Latar Belakang}

PT. Sumber Urip Sejati adalah perusahaan yang bergerak di bidang Karoseri dan juga distributor velg. Dalam produksi trailer ada beberapa tahap untuk menghasilkan sebuah produk trailer, yaitu tahap perakitan, tahap pengecatan dan terakhir adalah tahap pemasangan aksesoris. Tata letak PT. Sumber Urip Sejati memiliki kekurangan yaitu layout yang tidak menguntungkan dalam segi material handling.

Layout yang tidak teratur akan membuat proses produksi akan memakan waktu dan juga biaya material handling yang membengkak. Penempatan stok velg yang tidak tertata membuat ruang produksi trailer menjadi sempit hingga mempersulit penggunaan alat material handling. Pada tahap-tahap produksi mempunyai proses yang berurut namun pada kenyataannya tahap yang berurut tidak didukung oleh penempatan stasiun pengerjaan yang berurut juga.

Pada penataan tata letak fasilitas ada beberapa fasilitas yang peletakannya satu sama lain mempunyai jarak material handling yang jauh, seperti bagian Area Pengerjaan III yang letaknya jauh dari tempat parkir trailer yang sudah jadi dan juga sebagai inspeksi trailer. Peletakan yang baik seharusnya dekat dengan parkiran trailer karena Area Pengerjaan III merupakan stasiun terakhir dalam proses produksi trailer. Begitu juga dengan gudang spare parts yang letaknya di sudut perusahaan, 
seharusnya peletakan gudang spare part berada

diantara area Pengerjaan I, II, dan 
III sehingga memudahkan pengambilan spare parts.

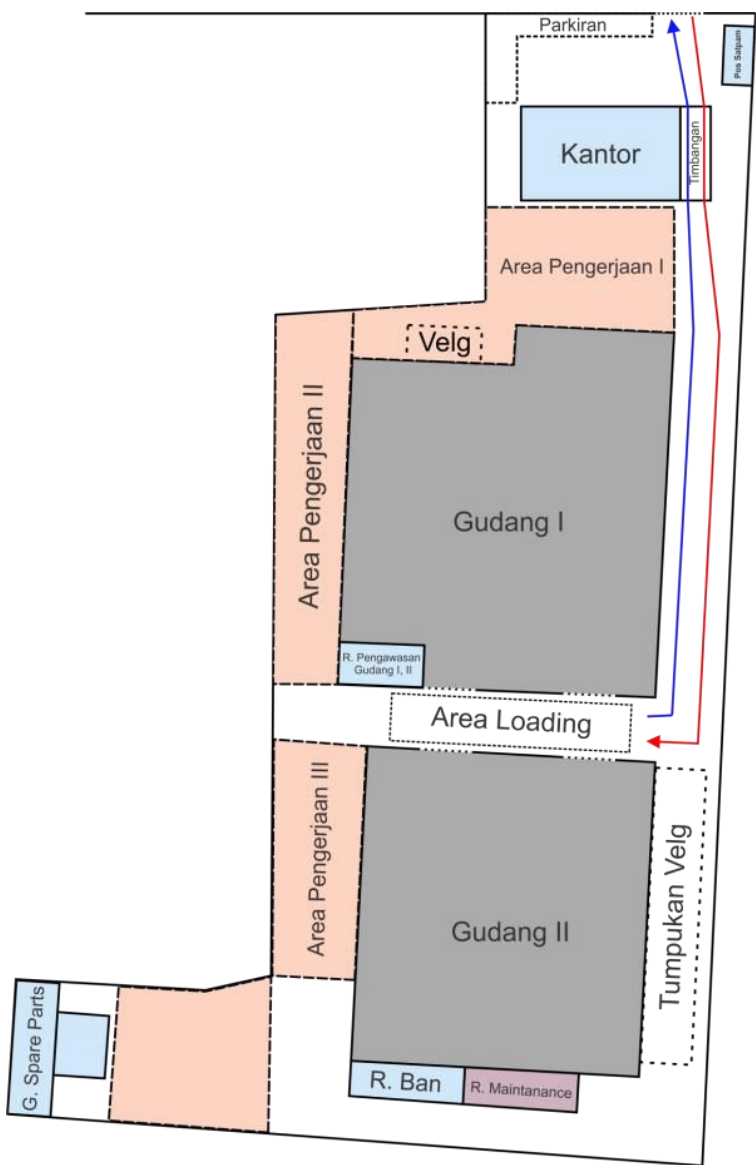

Gambar 1.1 Layout Awal PT. Sumber Urip Sejati

\subsection{Perumusan Masalah}

Dari uraian latar belakang di atas permasalahan yang dapat dirumuskan bahwa tata letak pada PT. Sumber Urip Sejati masih belum masksimal sehingga menghasilkan jarak perpindahan material handling yang tidak maksimal. PT. Sumber Urip Sejati mempunyai peluang untuk mengurangi jarak material handling dengan cara memperbaiki tata letak fasilitas khususnya pada fasilitas yang berhubungan dengan proses produksi karena peregerakan material handling kebanyakan berasal dari proses produksi. Permasalahan pada tata letak juga akan mempengaruhi aliran proses produksi yang tidak maksimal akibat dari alur perpindahan material yang belum maksimal (jarak perpindahan material yang panjang). Sehingga saya mengusulkan untuk "Perancangan ulang tata letak fasilitas menggunakan metode MultiObjective Function dan simulasi Arena.

\subsection{Tujuan Penelitian}

Tujuan dari penelitian ini adalah mengadakan studi dan evaluasi terhadap permasalahan yang telah dijelaskan sebelumnya. Tujuan penelitian ini adalah sebagai berikut :

a) Mengurangi jarak perpindahan material handling.

b) Merancang ulang tata letak fasilitas yang berhubungan dengan produksi di PT. Sumber Urip Sejati.

c) Mengevaluasi layout yang lama dengan layout usulan.

\subsection{Manfaat penelitian}

Dari hasil penelitian mengenai perancangan tata letak fasilitas pada PT. Sumber Urip Sejati dapat memeperoleh beberapa manfaat, antara lain :

a) Mengetahui tata letak pabrik yang berpotensi untuk meningkatkan efektifitas produksi.

b) Dapat mengurangi jarak material handling,.

Mengetahui performa layout usulan, dengan layout awal sebagai perbandingan.

\section{LANDASAN TEORI}

\subsection{Defenisi Tata Letak Pabrik}

Salah satu rekayasa yang bertujuan menangani pemindahan, perancangan suatu kegiatan industri manufaktur yang menggambarkan hasil rancangan sebagai tata letak pabrik (Layout). Tata letak fasilitas berhubungan dengan perencanaan penyusunan fasilitas fisik serta jumlah kebutuhna tenaga kerja dalam menghasilkan suatu produk. Peranan tata letak fasilitas adalah untuk membentuk aliran material 
maupun tenaga kerja menjadi lancar sehinga proses produksi dapat berlang sung secara efisien.

\subsection{Defenisi Perancangan Tata Letak Fasilitas}

Studi pengaturan tata letak fasilitas produksi selalu ditujukan untuk meminimalkan total cost, yang dalam hal ini elemen-elemen cost antara lain; construction cost, installation cost, material handling cost production cost, machin down time, safety cost, in-pocess storage cost. Dari beberap elemen-elemen biaya tersebut yang dianggpap paling berpengaruh dan berkaitan erat dengan perancangan tata letak layout (Layout Design) adalah material handling cost. Dalam suatu kegiatan produksi biaya yang dikeluarkan untuk pemindahan material bisa berkisar antara 30\% sampai dengan $90 \%$ dari total biaya produksi. Dengan demikian minimalisasi biaya material handling akan merupakan kirteria keberhasilan dari fase perancangan tata letak fasilitas dalam sebuah pabrik. (Sritomo Wignjosoebroto, 2003).

\subsection{MOF (Multi-Objective Function)}

\subsubsection{Jarak Tempuh (Travel Distance)}

Jarak tempuh (travel distance) adalah jarak yang dicapai selama terjadi pergerakan material, pekerja, dan peralatan dari satu fasilitas ke fasilitas yang lain. Berikut ini adalah perumusan hubungan jarak antar fasilitas dan frekuensi perpindahan antar fasilitas ke dalam persamaan berikut :

$T D=\sum_{i=1}^{n} \sum_{j=1}^{n} d_{i j} * F_{i j}$

Keterangan :

$T D=$ Hubungan antara jarak tempuh dengan frekuensi perpindahan antar fasilitas

$n$ = Jumlah fasilitas (nonfixed facilities dan fixed facilities)

$d_{i j}=$ Jarak aktual antara fasilitas $i$ dan $j$

$F_{i j}=$ Frekuensi perpindahan antar fasilitas $i$ dan $j$

\subsubsection{Tingkat Keamanan (Safety Index)}

Ketidakteraturan dalam penataan site layout dapat berpengaruh terhadap keamanan lokasi bagi para pekerja. Berikut ini adalah persamaan untuk ketidakamanan fasilitas dengan frekuensi perpindahan antar fasilitas :

$S I=\sum_{i=1}^{n} \sum_{j=1}^{n} S_{i j} * F_{i j}$

$T D=$ Hubungan antara keamanan dengan frekuensi perpindahan antar fasilitas

$n$ = Jumlah fasilitas (nonficed facilities dan fixed facilities)

$d_{i j}=$ Tingkat keselamatan antara fasilitas $i$ dan $j$

$F_{i j}=$ Frekuensi perpindahan antar fasilitas $i$ dan $j$

\subsection{Fungsi Objektif}

Fungsi objektif (objectives function) adalah fungsi tujuan atau sasaran yang akan dioptimalkan nilainya. Pada kasus optimasi site layout, fungsi objektif yang ingin dicapai adalah nilai jarak tempuh yang ingin diminimalkan. Fungsi tersebut dinyatakan dalam persamaan berikut :

$\operatorname{Min} T D=\sum_{i=1}^{n} \sum_{j=1}^{n} d_{i j} * F_{i j}$

Fungsi objektif yang ingin dicapai adalah nilai Tingkat Keamanan yang ingin diminimalkan. Fungsi tersebut dinyatakan dalam persamaan berikut :

Min. SI $=\sum_{i=1}^{n} \sum_{j=1}^{n} S_{i j} * F_{i j}$

\subsection{Permodelan Sistem}

Sistem adalah sekumpulan objek yang tergabung dalam suatu interaksi atau kesaling tergantungan atau interpedensi yang teratur. Pendapat yang lain ialah sistem didefinisikan sebagai sekumpulan elemen yang salin berinteraksi untuk mencapai tujuan dalam suatu lingkungan yang kompleks. Dengan demikian 
suatu sistem akan mengandung ciri-ciri sebagai berikut :

1. Di bangun oleh berbagai elemen yang saling berkaitan satu dengan yang lain.

2. Mempunyai tujuan yang mendasari keberadaanya.

3. Mempunyai kegiatan berupa proses trasnformasi input menjadi output

4. Adanya suatu mekanisme yang mengendalikan pengoperasiannya terutama dalam kaitannya dengan perubahan-perubahan yang terjadi pada linglunan dimana sistem itu berada.

Berangkat dari pengertian tersebut, pada dasarnya perancangan sistem merupakan suatu permodelan sistem (Building System).

\section{METODE}

\subsection{Lokasi \& Waktu Penelitian}

Penelitian ini dilakukan di PT. Sumber Urip Sejati yang mulai berdiri pada tahun 1965 di daerah kawasan industri daerah Margomulyo, yang beralamat lengkap J1. Margomulyo No. 63 Greges, Tandes, Kota Surabaya, Jawa Timur dengan Kode Pos 60186. Peneliti memilih PT. Sumber Urip Sejati sebagai tempat penelitian karena tersedia sarana yang mendukung untuk melakukan penelitian dibidang manufaktur. Penelitian ini juga terbatas hanya untuk daerah kerja PT. Sumber Urip Sejati.

Penelitian ini dilakukan selama 1 bulan yaitu dari tanggal 22 Januari sampai dengan 22 Februari 2018. Penelitian dilakukan mengikuti jadwal kerja perusahaan untuk mendapatkan data-data yang terkait dengan penelitian.

\subsection{Metode Penelitian}

Penelitian ini dilaksanakan dengan metode deskriptif. Metode deskriptif adalah metode penelitian yang terperinci, sistematis dan terstruktur. Metode ini memfokuskan pada penggunaan angka dan juga menggunakan tabel, grafik, dan diagram untuk menunujukan hasil data yang didapat. Dalam penelitian yang dilakukan di PT. Sumber Urip Sejati, peneliti banyak mengumpulkan data berupa angka yang mempresentasikan jarak, waktu dan juga biaya. Begitu juga pengolahan data yang dilakukan meggunakan tabel dan juga perhitungan untuk memperoleh hasil.

\subsection{Diagram Aliran}

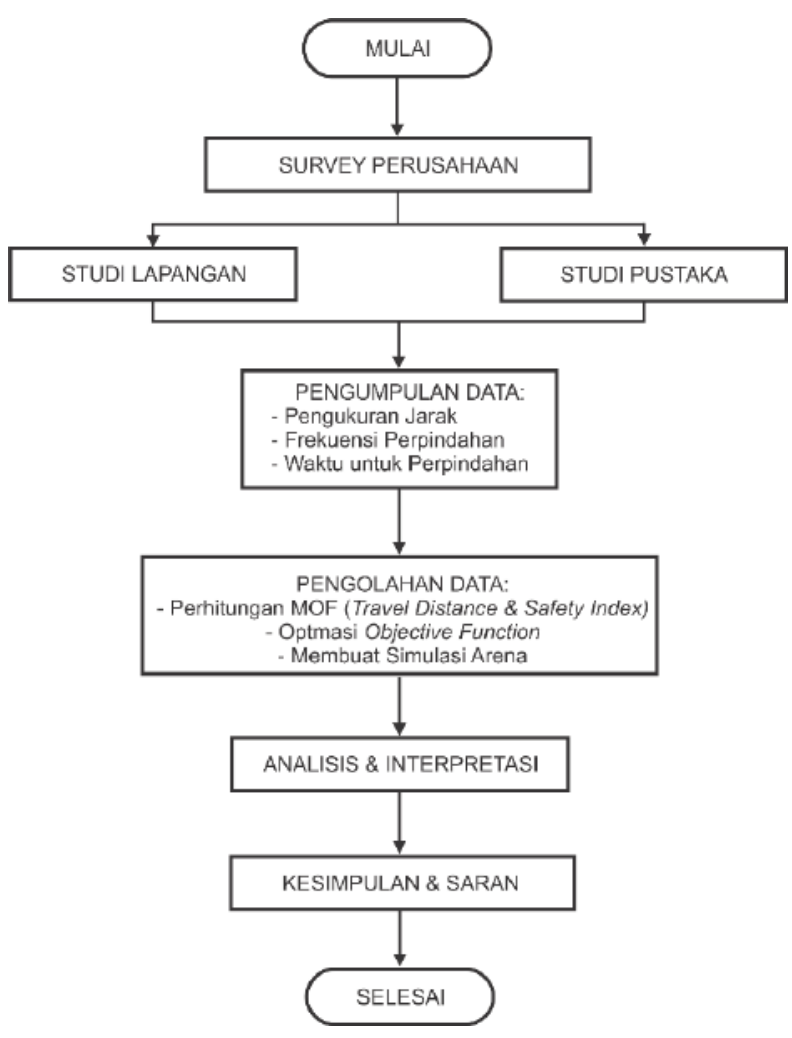

Gambar 3.1 Diagram Alir Penelitian

\section{HASIL DAN PEMBAHASAN}

\subsection{Pengumpulan Data}

Peneliti telah mengumpulkan data mengenai jarak antar fasilitas dengan melakukan pengukuran langsung dilapangan. Data ini akan digunakan untuk melakukan perhitungan Travel Distance. Jarak yang diukur merupakan jarak dari satu fasilitas dengan fasilitas lainya. 
Tabel 4.1 Jarak Antar Fasilitas

\begin{tabular}{|c|c|c|c|c|c|c|c|c|c|c|c|}
\hline $\begin{array}{l}\text { larak } \\
\text { Aatar fasilitas } \\
\text { (ix) }\end{array}$ & Kantor & $\begin{array}{l}\text { Dept. } \\
\text { Rerrakit } \\
\text { and(m) }\end{array}$ & $\begin{array}{l}\text { Dept. } \\
\text { Resagss } \\
\text { atas }\end{array}$ & $\begin{array}{c}\text { Dept. } \\
\text { Akssess } \\
\text { ris }\end{array}$ & $\frac{\mathrm{Gds}}{\mathrm{I}}$ & $\frac{\mathrm{Gd} q}{\mathrm{II}}$ & $\begin{array}{l}\text { RPengas } \\
\text { swas Gids } \\
\text { I\& II }\end{array}$ & G.Sig. & $\frac{\text { Ruang }}{\text { Ban }}$ & $\begin{array}{l}\text { Ruang } \\
\text { Maintana } \\
\text { aSG }\end{array}$ & $\begin{array}{l}\text { Bakji } \\
\text { ana }\end{array}$ \\
\hline Kantior & & 15 & & & 79 & 88 & 77 & 205 & 180 & 185 & 16 \\
\hline Depc. Berakitan & 15 & & 18 & 120 & 71 & 79 & 66 & 194 & 182 & 187 & 26 \\
\hline $\begin{array}{c}\text { Dept. } \\
\text { Peagcatan }\end{array}$ & 26 & 18 & 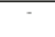 & 29 & 23 & 44 & 17 & 128 & 115 & 118 & 49 \\
\hline Dept Alssescois & 69 & 120 & 29 & - & 27 & 40 & 26 & 65 & 53 & 55 & 79 \\
\hline Gudang I & 79 & 71 & 23 & 27 & & 17 & 0 & 113 & 95 & 100 & 90 \\
\hline Gudang II & 88 & 79 & 44 & 40 & 17 & & 15 & 122 & 89 & 94 & 97 \\
\hline $\begin{array}{l}R \text { pentiaswas } \\
\text { gudang }\end{array}$ & 37 & 66 & 17 & 26 & 0 & 15 & 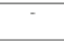 & 115 & 98 & 103 & 93 \\
\hline G. $\mathrm{SP}$ & 205 & 194 & 128 & 65 & 113 & 122 & 115 & - & 65 & 66 & 209 \\
\hline R.Ban & 180 & 182 & 115 & 53 & 95 & 89 & 98 & 65 & & 6 & 196 \\
\hline R. Maintanances & 185 & 187 & 118 & 55 & 100 & 94 & 103 & 66 & 6 & & 198 \\
\hline Rarikran & 16 & 26 & 49 & 79 & 90 & 97 & 93 & 209 & 196 & 198 & \\
\hline
\end{tabular}

Dalam mencari Travel Distance peneliti juga mengumpulkan data mengenai frekuensi perpindahan material antar fasilitas. Data frekuensi didapatkan dengan melakukan pengamatan dan juga wawancara dengan Kepala Divisi Lapangan. Data frekuensi perpindahan ini merupakan frekuensi perpindahan dalam satu hari. Frekuensi perpindahan bisa dilihat pada Tabel 4.2.

Tabel 4.2 Frekuensi Perpindahan Antar Fasilitas

\begin{tabular}{|c|c|c|c|c|c|c|c|c|c|c|c|}
\hline $\begin{array}{l}\text { Erekuensi } \\
\text { Pempindaban } \\
\text { (Kali hari) }\end{array}$ & Kantor & $\begin{array}{l}\text { Dept } \\
\text { Perakit } \\
\text { an }\end{array}$ & $\begin{array}{l}\text { Dept } \\
\text { Peneesit } \\
\text { an }\end{array}$ & $\begin{array}{l}\text { Dept. } \\
\text { Aksesog } \\
\text { ris }\end{array}$ & $\frac{\mathrm{gdg}}{\mathrm{I}}$ & $\frac{\text { Gdg }}{\text { II }}$ & 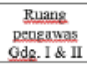 & S.Sp & $\frac{\text { Ruang }}{\text { Ban }}$ & $\begin{array}{l}\text { Ruans } \\
\text { Maints } \\
\text { pance }\end{array}$ & $\frac{\text { Parki }}{\mathrm{ran}}$ \\
\hline Kantor & - & 4 & 2 & 2 & 6 & 6 & 13 & 10 & 0 & 0 & 34 \\
\hline Dept. Perrakitan & 4 & - & 3 & 0 & 5 & 8 & 4 & 14 & 4 & 2 & 12 \\
\hline $\begin{array}{c}\text { Dept. } \\
\text { Pengecatan }\end{array}$ & 2 & 3 & - & 3 & 0 & 0 & 0 & 6 & 0 & 1 & 6 \\
\hline Dept. Aksesaris & 2 & 0 & 3 & - & 0 & 2 & 2 & 11 & 2 & 0 & 6 \\
\hline Gudang I & 6 & 5 & 0 & 0 & & 36 & 12 & 2 & 8 & 0 & 16 \\
\hline Gudang II & 6 & 8 & 0 & 2 & 36 & - & 14 & 12 & 6 & 0 & 12 \\
\hline $\begin{array}{l}\text { R. pengauras } \\
\text { gudang }\end{array}$ & 13 & 4 & 6 & 2 & 12 & 14 & - & 4 & 3 & 0 & 6 \\
\hline$G S_{P}$ & 10 & 14 & 6 & 11 & 2 & 12 & 4 & . & 6 & 5 & 4 \\
\hline R. Ban & 0 & 4 & 0 & 2 & 8 & 6 & 3 & 6 & - & 2 & 4 \\
\hline R. Maintanance & 0 & 2 & 1 & 0 & 0 & 0 & 0 & 5 & 2 & - & 4 \\
\hline Parkiran & 34 & 12 & 6 & 6 & 16 & 12 & 6 & 4 & 4 & 4 & - \\
\hline
\end{tabular}

Dari safety layout yang didapatkan dari wawancara dengan kepala Divisi Lapangan untuk pemberian tingkat Safety Index, pemberian nilai bobot pada tiap tingkat yaitu Tingkat 1 dengan nilai dari $1-1,5$, Tingkat 2 dengan nilai dari $1,5-$ 2 , Tingkat 3 yaitu dengan nilai dari $2-2,5$ dan Tingkat 4 dengan nilai dari 2,5-3,5.

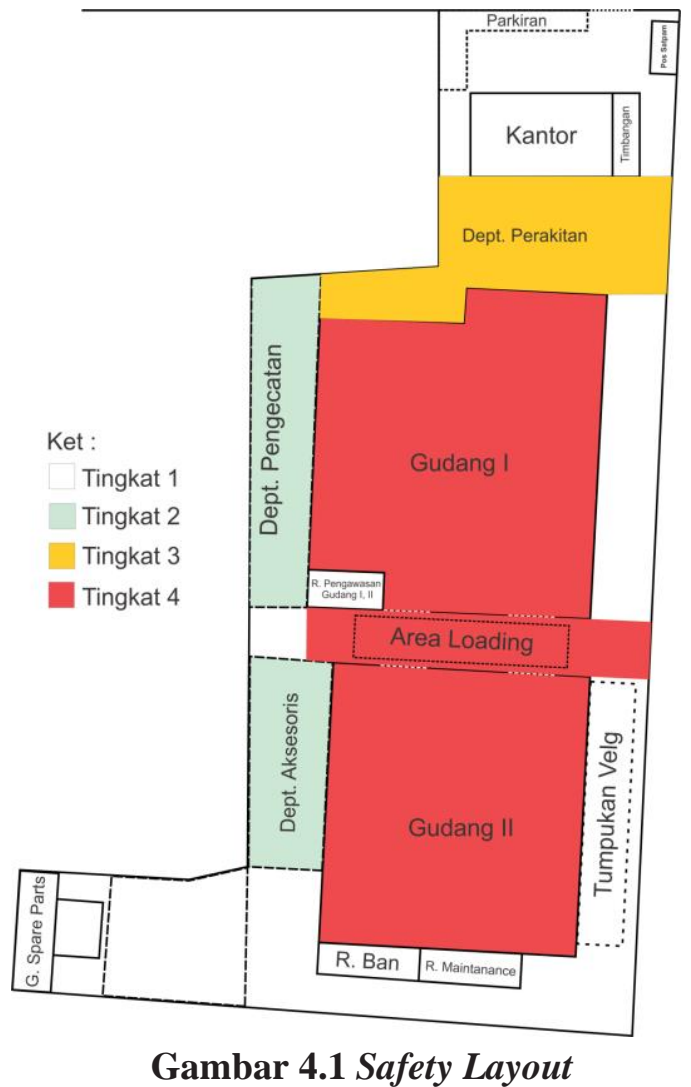

Dari pemberian bobot nilai pada tiap tingkat di safety layout maka peneliti bisa mengetahui nilai safety index dalam perpindahan antar fasilitas. Selanjutnya peneliti melakukan wawancara dengan Kepala Divisi Lapangan unuk memberikan nilai safety index untuk perpindahan antar fasilitas, kemudian bisa dibuat tabel safety index fasilitas sebagi berikut.

Tabel 4.3 Safety Index antar Fasilitas

\begin{tabular}{|c|c|c|c|c|c|c|c|c|c|c|c|}
\hline $\begin{array}{l}\text { Safery Index } \\
\text { (Nilai } \\
\text { resikotravel) }\end{array}$ & $\begin{array}{c}\text { Kant } \\
\text { or }\end{array}$ & $\begin{array}{l}\text { Dept. } \\
\text { Perakit } \\
\text { an }\end{array}$ & $\begin{array}{l}\text { Dept. } \\
\text { Pengec } \\
\text { atman }\end{array}$ & $\begin{array}{l}\text { Dept. } \\
\text { Alseso } \\
\text { nis }\end{array}$ & $\frac{\mathrm{Gdg}}{\mathrm{I}}$ & $\frac{\mathrm{Gdg}}{\mathrm{II}}$ & $\begin{array}{c}\text { Ruang } \\
\text { pengawas } \\
\text { gudang I \& II }\end{array}$ & G.Sp & $\frac{\text { Ruang }}{\text { Ban }}$ & $\begin{array}{l}\frac{\text { Ruang }}{\text { Mainta }} \\
\text { nance }\end{array}$ & $\frac{\text { Parki }}{\text { ran }}$ \\
\hline Kantor & $\cdot$ & $\frac{\pi}{2}$ & 2,5 & 2,5 & 3,5 & 3,5 & $\frac{\text { gudang a d II }}{3,2}$ & 2,1 & 21 & $\frac{1 \text { since }}{2,1}$ & 2,3 \\
\hline $\begin{array}{c}\text { Dept. } \\
\text { Perakitan }\end{array}$ & 2 & . & 2,6 & 2,8 & 2,7 & 2,7 & 3,1 & 2,8 & 2,7 & 2,7 & 3 \\
\hline $\begin{array}{c}\text { Dept. } \\
\text { Pengecatan }\end{array}$ & 2,5 & 2,6 & - & 1,6 & 1,9 & 1,9 & 1,7 & 1,6 & 1,5 & 1,5 & 2.1 \\
\hline $\begin{array}{c}\text { Dept. } \\
\text { Aksesoris }\end{array}$ & 2,5 & 2,8 & 1,6 & - & 1,7 & 1,7 & 1,6 & 1,6 & 1,4 & 1,4 & 2,3 \\
\hline Gudang I & 3,5 & 2,7 & 1,9 & 1.7 & 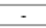 & 3,5 & 2.9 & 3 & 2.8 & 2.8 & 2.5 \\
\hline Gudang II & 3,5 & 2,7 & 1,9 & 1.7 & 3,5 & - & 3,1 & 2.9 & 2.7 & 2.7 & 2.6 \\
\hline $\begin{array}{l}\text { R. pengawass } \\
\text { gudang }\end{array}$ & 3,2 & 3,1 & 1,7 & 1,6 & 2,9 & 3,1 & $\cdot$ & 2,7 & 2,6 & 2,6 & 2,6 \\
\hline $\mathrm{G}_{\mathrm{G} . \mathrm{S}_{\mathrm{P}}}$ & 2,1 & 2,8 & 1,6 & 1,6 & 3 & 2,9 & 2,7 & - & 1.2 & 1,2 & 2,9 \\
\hline R. Ban & 2,1 & 2,7 & 1.5 & 1,4 & 2.8 & 2.7 & 2.6 & 1,2 & $\cdot$ & 1 & 2,8 \\
\hline $\begin{array}{c}\mathrm{R} \\
\text { Maintanance }\end{array}$ & 2,1 & 2.7 & 1.5 & 1,4 & 2,8 & 2,7 & 2,6 & 1,2 & 1 & . & 2,8 \\
\hline Parkiran & 2,3 & 3 & 2.1 & 2.3 & 2.5 & 2.6 & 2.6 & 2.9 & 2.8 & 2,8 & - \\
\hline
\end{tabular}


Tabel 4.4 Waktu Perpindahan antar fasilitas dalam line production

\begin{tabular}{|c|c|c|c|c|}
\hline No & Lokasi & 1 & 2 & 3 \\
\hline Lokasi & $\begin{array}{c}\text { Waktu Perpindahan } \\
\text { (menit/1x) }\end{array}$ & $\begin{array}{c}\text { Dept. } \\
\text { Perakitan }\end{array}$ & $\begin{array}{c}\text { Dept. } \\
\text { Pengecatan }\end{array}$ & $\begin{array}{c}\text { Dept. } \\
\text { Aksesoris }\end{array}$ \\
\hline 1 & Dept. Perakitan & - & 25 & 20 \\
\hline 2 & Dept. Pengecatan & 25 & - & 18 \\
\hline 3 & Dept. Aksesoris & 20 & 18 & - \\
\hline
\end{tabular}

Tabel 4.5 Tabel Lama Waktu Pengerjaan Tiap Departemen Produksi

\begin{tabular}{|c|c|c|c|}
\hline Fasilitas & Dept. Perakitan & Dept. Pengecatan & Dept. Aksesoris \\
\hline $\begin{array}{c}\text { Waktu Tiap Pengerjaan } \\
\text { produk (hari) }\end{array}$ & 7 & 3 & 2 \\
\hline
\end{tabular}

\subsection{Pengolahan Data}

\subsubsection{Multi-objective Function}

Setelah dikumpulkan semua data maka langkah berikutnya adalah melakukan perhitungan dengan menggunak MOF. Dalam perhitungan MOF akan dilakukan dua perhitungan yaitu Travel Distance (TD) dan Safety Index (SI).

Minimize $T D=\sum_{i=1}^{n} \sum_{j=1}^{n} d_{i j} * F_{i j}$

Minimize $S I=\sum_{i=1}^{n} \sum_{j=1}^{n} S_{i j} * F_{i j}$

Ket :

$d$ : Farak

$F \quad$ : Frekuensi

$i j$ : Fasilitas ke fasilitas

$S$ : Nilai Safety

Perlu diketahui bahwa pada perubahan disetiap skenario dengan kondisi equal site layout, pertukaran terjadi hanya pada fasilitas sejenis. Terdapat dua jenis fasilitas yaitu fasilitas ruang terbuka dan ruang tertutup. Untuk ruang terbuka melingkupi departemen-departemen produksi dan parkiran. Sedangkan untuk ruang tertutup melingkupi kantor, gudang dan ruangan-ruangan lainnya.

\section{Tabel 4.6 Daftar Pertukaran Fasilitas} dalam Skenario

\begin{tabular}{|c|c|c|}
\hline Skenario & \multicolumn{2}{|c|}{ Fasilitas yang ditukar } \\
\hline 0 (eksisting) & - & - \\
\hline $\mathbf{1}$ & Gudang Spareparts & R. Maintenance \\
\hline \multirow{2}{*}{} & Dept. Perakitan & Dept. Pengecatan \\
\cline { 2 - 3 } & Gudang I & Gudang II \\
\hline \multirow{2}{*}{} & Dept. Perakitan & Dept. Aksesoris \\
\cline { 2 - 3 } & G. Spareparts & Ruang Ban \\
\hline \multirow{2}{*}{} & Dept. Pengecatan & Dept. Aksesoris \\
\cline { 2 - 3 } & Ruang Ban & R. Maintenance \\
\hline
\end{tabular}

- $\quad$ Skenario 0, Kondisi awal (Eksisting)

Pada skenario 0, yaitu awal atau layout real fasilitas masih dalam posisi aslinya karena belum ada pemindahan fasilitas. Pada skenario ini akan dijadikan patokan akan apakah akan kenaikan atau penurunan.

Tabel 4.7 Frekuensi antar fasilitas $\left(F_{i j}\right)$ Skenario 0 (Eksisting)

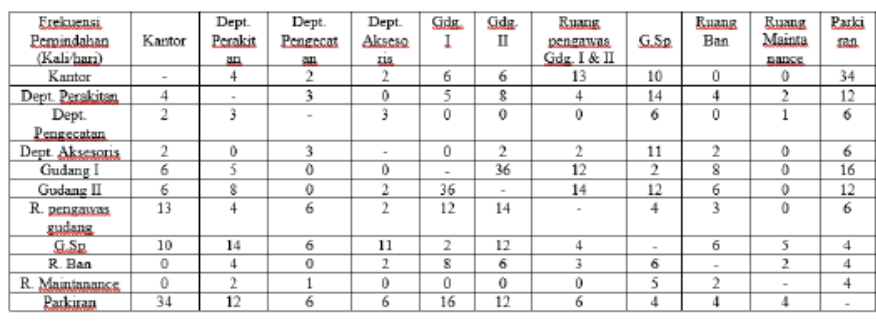


Tabel 4.8 Jarak antar fasilitas $\left(d_{i j}\right)$ Skenario 0 (Eksisting)

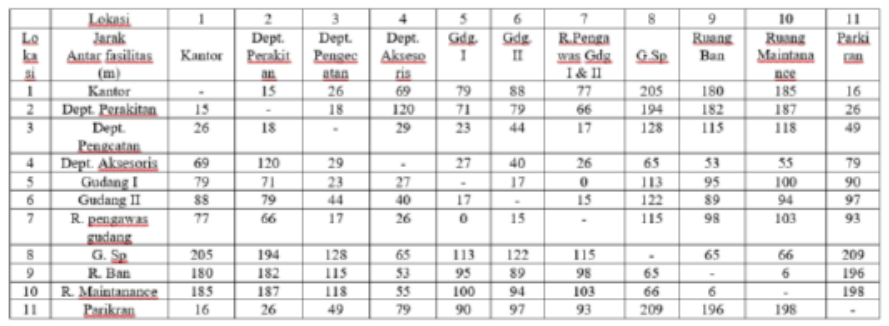

Tabel 4.9 Hasil Skenario 0 TD $\left(d_{i j} * F_{i j}\right)$

\begin{tabular}{|c|c|c|c|c|c|c|c|c|c|c|c|c|c|}
\hline & Loknii & 1 & 2 & 3 & 4 & 5 & 6 & 7 & 8 & 9 & 10 & 11 & \\
\hline$\frac{6}{\mathrm{k}}$ & Easilitas & $\begin{array}{c}\text { Kant } \\
\text { or }\end{array}$ & $\begin{array}{l}\text { Dept } \\
\text { Perakit } \\
\text { ant }\end{array}$ & $\begin{array}{l}\text { Dept. } \\
\text { Panase } \\
\text { athan }\end{array}$ & $\begin{array}{l}\text { Depe } \\
\text { Alksese } \\
\text { iis }\end{array}$ & $\frac{\mathrm{s}_{2}}{\mathrm{l}}$ & $\frac{\mathrm{Oda}}{\mathrm{II}}$ & 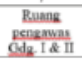 & ${\mathrm{G} . S_{2}}_{2}$ & $\begin{array}{c}\text { R. } \\
\text { Ban }\end{array}$ & 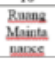 & $\begin{array}{c}\text { Parki } \\
\text { man }\end{array}$ & Total \\
\hline 1 & Kantor & . & & & & 474 & 528 & & 2050 & 0 & & 544 & 4847 \\
\hline 2 & $\begin{array}{l}\text { Dept } \\
\text { Pentitat }\end{array}$ & 60 & . & 54 & 0 & 355 & 632 & 264 & 2716 & 728 & 374 & 312 & 5495 \\
\hline 3 & $\begin{array}{c}\text { Dept. } \\
\text { Penpesating }\end{array}$ & 52 & 54 & - & 87 & 0 & 0 & 0 & 768 & 0 & 118 & 294 & 1373 \\
\hline 4 & $\begin{array}{l}\text { Dept } \\
\text { Akestogis }\end{array}$ & 138 & 0 & 87 & $\cdot$ & 0 & 80 & 52 & 715 & 106 & 0 & 474 & 1652 \\
\hline 5 & Gudkag 1 & 474 & 355 & 0 & 0 & . & 612 & 0 & 226 & 760 & 0 & 1440 & 3867 \\
\hline 6 & Ovdang II & 528 & 632 & 0 & 80 & 612 & 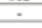 & 210 & 1464 & 534 & 0 & 1164 & 5224 \\
\hline & 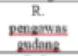 & 1001 & 264 & 102 & 52 & 0 & 210 & - & 460 & 294 & 0 & 958 & 2941 \\
\hline 8 & $\cos 2$ & 2050 & 2716 & 768 & 713 & 226 & 1464 & 460 & & 390 & 330 & 836 & 9953 \\
\hline$\frac{9}{10}$ & $\frac{\text { R. Ban }}{R}$ & 0 & 728 & 0 & 106 & 760 & 534 & 294 & 390 & & 12 & 784 & 3608 \\
\hline & $\begin{array}{l}R \\
\text { Maintanes }\end{array}$ & 0 & 374 & 118 & 0 & 0 & 0 & 0 & 330 & 12 & . & 792 & 1626 \\
\hline II & Parkinal & 344 & 312 & 294 & 474 & 1440 & 1164 & 358 & 836 & 784 & 792 & & 7198 \\
\hline
\end{tabular}

Tabel 4.10 Safety Index antar fasilitas $\left(s_{i j}\right)$ Skenario 0 (Eksisting)

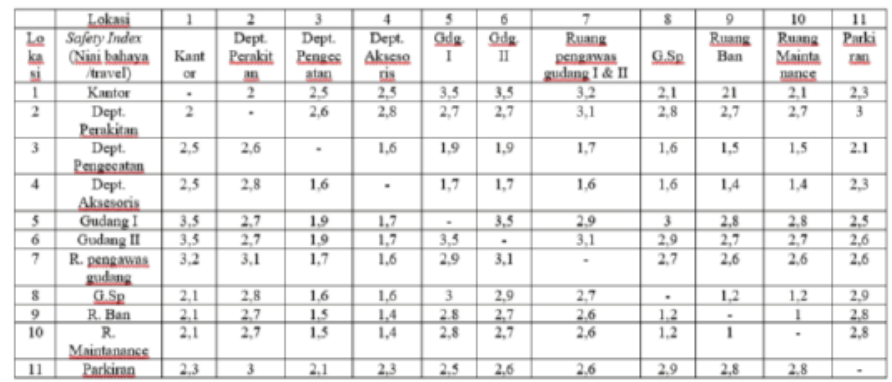

Tabel 4.11 Hasil Skenario 0 SI

$$
\left(\boldsymbol{S}_{i j} * \boldsymbol{F}_{i j}\right)
$$

\begin{tabular}{|c|c|c|c|c|c|c|c|c|c|c|c|c|c|}
\hline & Lokasi & 1 & 2 & 3 & 4 & 5 & 6 & 7 & 8 & 9 & 10 & 11 & \\
\hline$\frac{\mathrm{Le}}{\mathrm{ag}}$ & Easilitan & $\underset{\text { of }}{\text { onst }}$ & $\begin{array}{l}\text { Depe } \\
\text { Penkit }\end{array}$ & $\begin{array}{l}\text { Dept } \\
\text { Penges }\end{array}$ & $\begin{array}{l}\text { Dept. } \\
\text { Alkseis } \\
\text { ili }\end{array}$ & $\frac{\frac{G d a}{1}}{1}$ & $\frac{\mathrm{CN} / 2}{\mathrm{II}}$ & 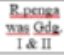 & $\underline{0 . S_{2}}$ & $\begin{array}{c}R \\
\text { Ban }\end{array}$ & $\begin{array}{l}\text { Ruang } \\
\text { Mainta } \\
\text { guncs }\end{array}$ & $\begin{array}{l}\text { Parki } \\
\text { nan }\end{array}$ & Total \\
\hline 1 & Kantor & & 8 & 5 & 5 & 21 & 21 & 41.6 & 21 & 0 & 0 & 78.2 & 179,8 \\
\hline 2 & $\begin{array}{c}\text { Dept } \\
\text { Periktan }\end{array}$ & 8 & $\cdot$ & 7,8 & 0 & 13,5 & 21,6 & 12,4 & 39.2 & 10,8 & 5,4 & 36 & 141,2 \\
\hline 3 & $\begin{array}{c}\text { Dept } \\
\text { Pengesstinn }\end{array}$ & 3 & 7,8 & . & 4,8 & 0 & 0 & 0 & 9,6 & 0 & 1,5 & 6,3 & 35 \\
\hline 4 & $\begin{array}{l}\text { Dept } \\
\text { Akesoris }\end{array}$ & 5 & 0 & 4,8 & $\cdot$ & 0 & 3,4 & 3,2 & 12,8 & 2,8 & 0 & 13,8 & 45,8 \\
\hline$\frac{5}{6}$ & Gudiang 1 & 21 & 13.5 & 0 & 0 & 126 & 126 & $\frac{34,6}{434}$ & 6 & 22.4 & 0 & $\frac{40}{312}$ & 263.9 \\
\hline 7 & R. peneaviat & 41,6 & 12,4 & 0 & 3,2 & $\begin{array}{l}126 \\
34,6\end{array}$ & 43,4 & 43,4 & 10,8 & $\frac{10,2}{7,8}$ & 0 & $\begin{array}{l}15,1,6 \\
15,6\end{array}$ & 169,0 \\
\hline 8 & $0 . \mathrm{sp}_{0}$ & 21 & 39.2 & 9,6 & 12.8 & 6 & 34,8 & 10,8 & & 7.2 & 6 & 11.6 & 159 \\
\hline 9 & R. Ban & 0 & 10.8 & 0 & 2.8 & 22.4 & 16.2 & 7,8 & 7,2 & 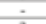 & 2 & 11,2 & 80,4 \\
\hline 10 & $\frac{\text { RMaintanas }}{s e}$ & 0 & 5,4 & 1,5 & 0 & & 0 & 0 & 6 & 2 & - & 11,2 & 26,1 \\
\hline 11 & Pankiran & 78,2 & 36 & 6,3 & 13,8 & 40 & 31,2 & 15,6 & 11.6 & 11,2 & 11,2 & $\because$ & 253,1 \\
\hline
\end{tabular}

Dari perhitungan ini didapatkan nilai TD sebesar 47786 meter sedangkan nilai SI sebesar 1649,9.

- Skenario 1,

Pada skenario ini dilakukan petukaran antar Ruang Maintenance dengan Gudang bahan baku dan spareparts.

\section{Tabel 4.12 Frekuensi antar fasilitas} $\left(F_{i j}\right)$ Skenario 1

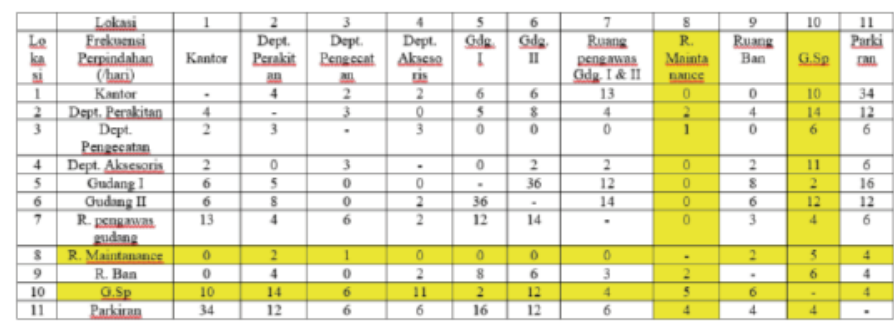

Tabel 4.13 Jarak antar fasilitas $\left(d_{i j}\right)$ Skenario 1

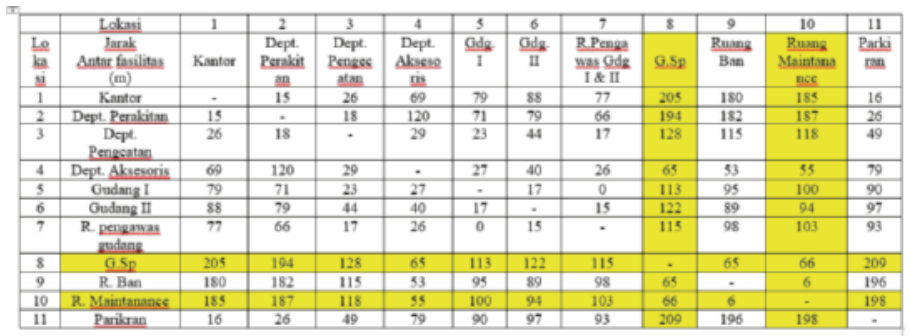

Tabel 4.14 Hasil Skenario 1 TD

$$
\left(d_{i j} * F_{i j}\right)
$$

\begin{tabular}{|c|c|c|c|c|c|c|c|c|c|c|c|c|c|}
\hline & Lokani & 1 & 2 & 3 & 4 & 5 & 6 & 7 & 8 & 9 & 10 & 11 & \\
\hline$\frac{\mathrm{k}}{\mathrm{ck}}$ & Ensilitas & $\begin{array}{c}\text { Kant } \\
\text { of }\end{array}$ & $\begin{array}{l}\text { Dept } \\
\text { Perakit } \\
\text { an }\end{array}$ & $\begin{array}{l}\text { Dept. } \\
\text { Pcrngss } \\
\text { stax }\end{array}$ & $\begin{array}{l}\text { Dept. } \\
\text { Alascss } \\
\text { ris }\end{array}$ & $\frac{\text { adg }}{1}$ & $\frac{\mathrm{ded}^{2}}{\mathrm{II}}$ & 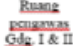 & $\begin{array}{l}\text { Ruang } \\
\text { Mraintas }\end{array}$ & $\begin{array}{c}\mathrm{R} \\
\mathrm{Bann}\end{array}$ & $\underline{0 . s_{p}}$ & $\begin{array}{c}\text { Parki } \\
\text { nn m }\end{array}$ & Total \\
\hline$\frac{\pi}{1}$ & Kantar & $\cdot$ & & & 138 & 474 & 528 & 1001 & 0 & 0 & 1850 & 544 & 4647 \\
\hline 2 & $\begin{array}{c}\text { Dept. } \\
\text { Peralitian }\end{array}$ & 60 & . & 54 & 0 & 355 & 632 & 264 & 388 & 728 & 2618 & 312 & $\$ 411$ \\
\hline 3 & $\begin{array}{c}\text { Dept. } \\
\text { Bengssaten }\end{array}$ & 52 & 54 & - & 87 & 0 & 0 & 0 & 128 & 0 & 908 & 294 & 1323 \\
\hline 4 & $\begin{array}{c}\text { Dept. } \\
\text { Alsesoris }\end{array}$ & 138 & 0 & 87 & - & 0 & 80 & 52 & 0 & 106 & 605 & 474 & 1542 \\
\hline 5 & Gudang 1 & 474 & 355 & 0 & 0 & - & 612 & 0 & 0 & 760 & 200 & 1440 & 3841 \\
\hline 6 & Gudang II & 528 & 632 & 0 & 80 & 612 & & 210 & 0 & 534 & 1128 & 1164 & 4858 \\
\hline & $\begin{array}{c}\mathrm{R} \\
\text { peneaguas } \\
\text { gudidna }\end{array}$ & 1001 & 264 & 102 & 52 & 0 & 210 & - & 0 & 294 & 412 & 558 & 2893 \\
\hline 8 & $\begin{array}{c}R \\
\text { Maintanane }\end{array}$ & 0 & 388 & 128 & 0 & 0 & 0 & 0 & - & 130 & 330 & 836 & 1812 \\
\hline 9 & R. Ban & 0 & 728 & 0 & 106 & 760 & 534 & 294 & 130 & $\therefore$ & 36 & 784 & 3372 \\
\hline 10 & 0. $5 \mathrm{~s}$ & 1850 & 2618 & 708 & 605 & 200 & 1128 & 412 & 330 & 36 & - & 792 & 8679 \\
\hline I1 & Parkiran & 544 & 312 & 294 & 474 & 144 & 1164 & 558 & 836 & 784 & 792 & - & 7198 \\
\hline
\end{tabular}


Tabel 4.15 Safety Index antar fasilitas $\left(s_{i j}\right)$ Skenario 1

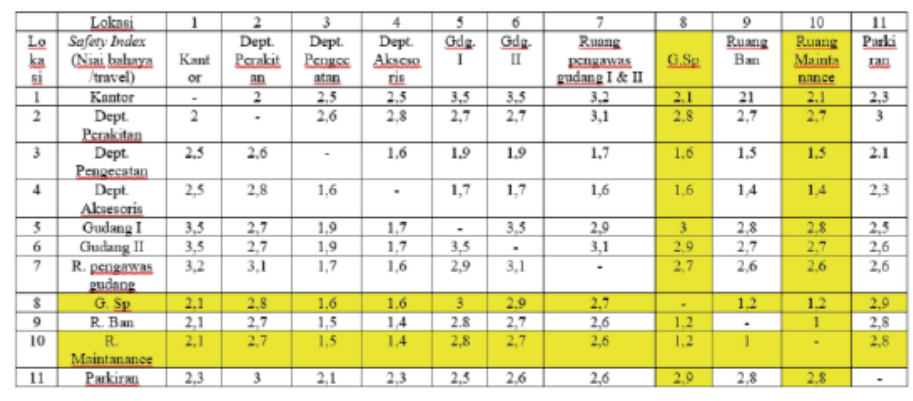

Tabel 4.16 Hasil Skenario 1 SI $\left(s_{i j}{ }^{*} F_{i j}\right)$

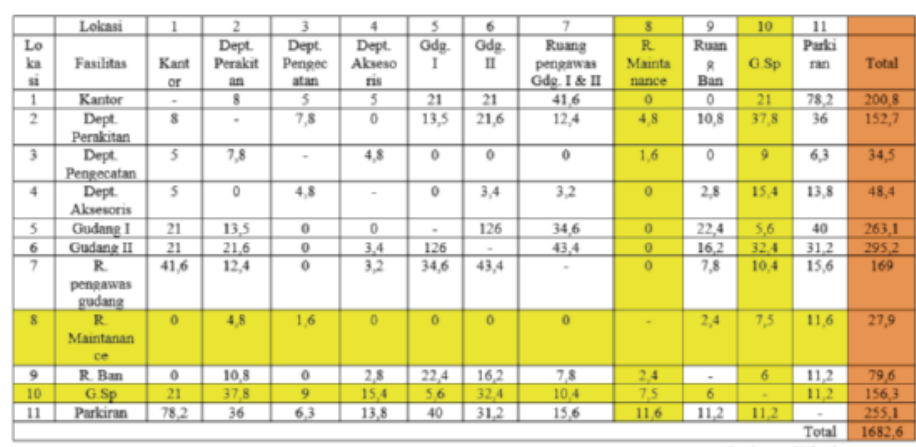

Dari skenario 1 didapatkan nilai TD sebesar 45606 meter dan nilai SI sebesar 1682,6.

- Skenario 2,

Pada skenario ini terjadi pertukaran pada 4 fasilitas, yaitu Departemen Perakitan bertukar lokasi dengan Departemen Pengecatan dan Gudang I bertukar lokasi dengan Gudang II.

Tabel 4.17 Frekuensi antar fasilitas $\left(F_{i j}\right)$ Skenario 2

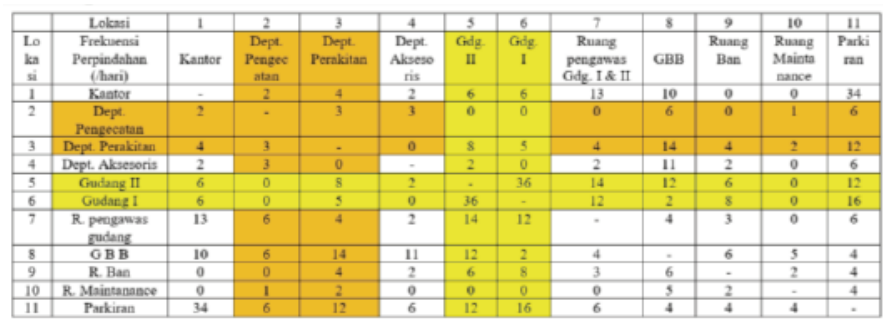

Tabel 4.18 Jarak antar fasilitas $\left(\boldsymbol{d}_{i j}\right)$

Skenario 2

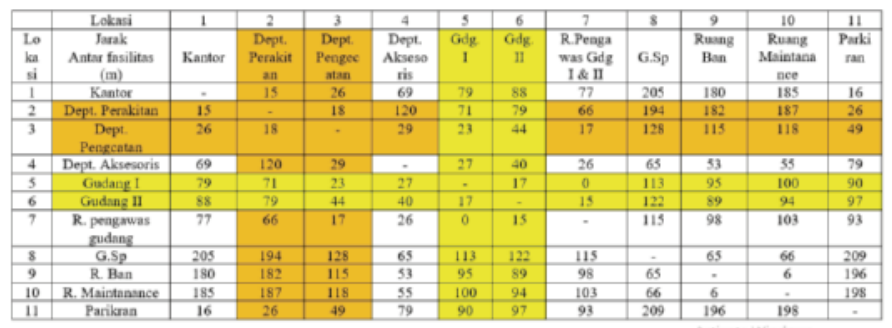

Tabel 4.19 Hasil Skenario 2 TD

$\left(d_{i j} * F_{i j}\right)$

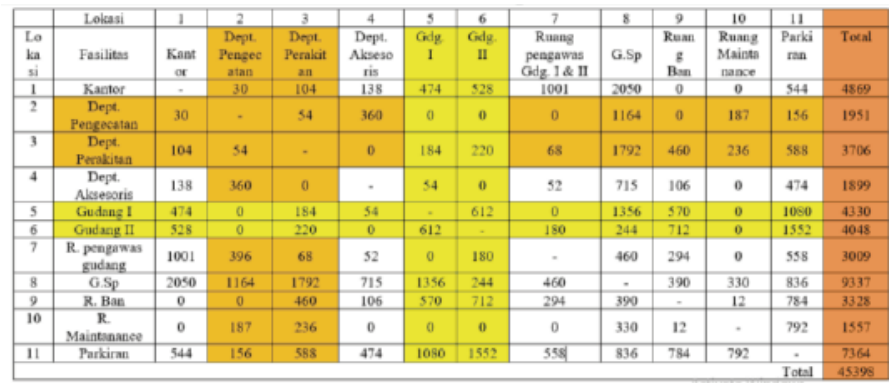

Tabel 4.20 Safety Index antar fasilitas $\left(s_{i j}\right)$ Skenario 2

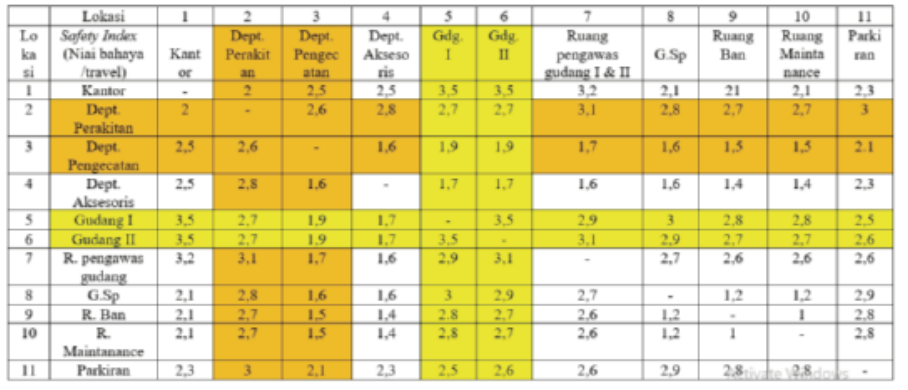

Tabel 4.21 Hasil Skenario 2 SI $\left(s_{i j} * F_{i j}\right)$

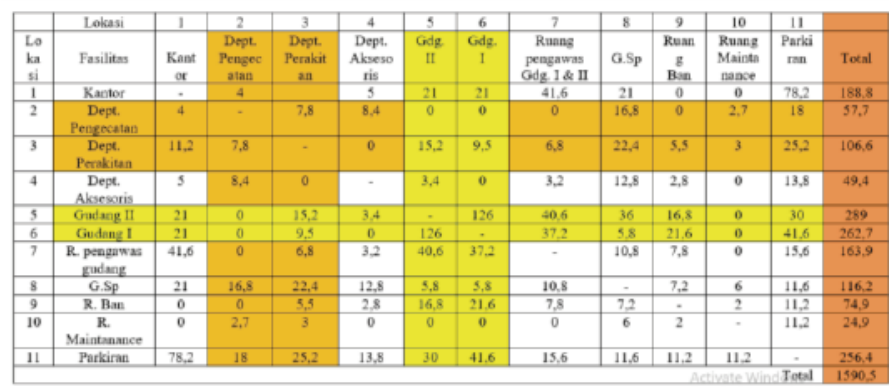

Dari hasil skenario 2 didapatkan hasil niali TD sebesar 45398 meter dan nilai SI sebesar 1590,5. 
- Skenario 3,

Pada skenario ini perubahan terjadi pada 4 fasilitas yaitu Departemen Perakitan bertukar lokasi dengan Departemen Aksesoris dan G. Spareparts bertukar lokasi dengan Ruang Ban.

\section{Tabel 4.22 Frekuensi antar fasilitas} $\left(F_{i j}\right)$ Skenario 3

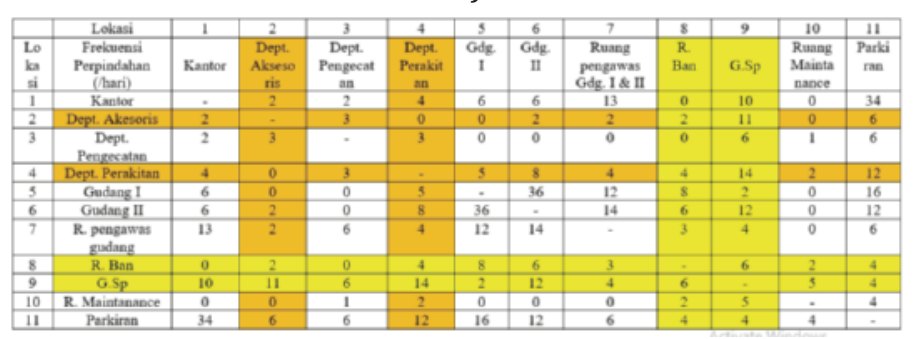

Tabel 4.23 Jarak antar fasilitas $\left(d_{i j}\right)$ Skenario 3

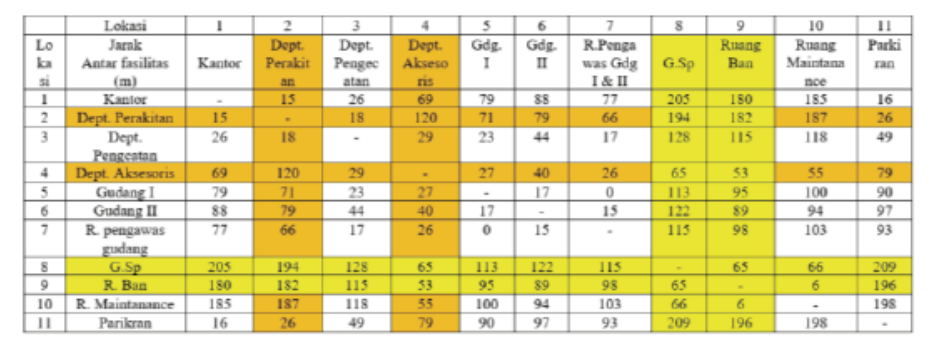

Tabel 4.24 Hasil Skenario 3 TD

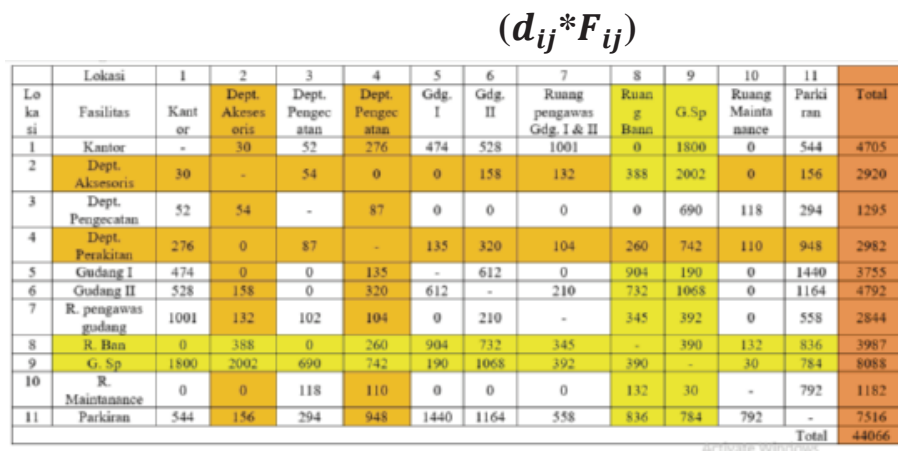

Tabel 4.25 Safety Index antar fasilitas $\left(s_{i j}\right)$ Skenario 3

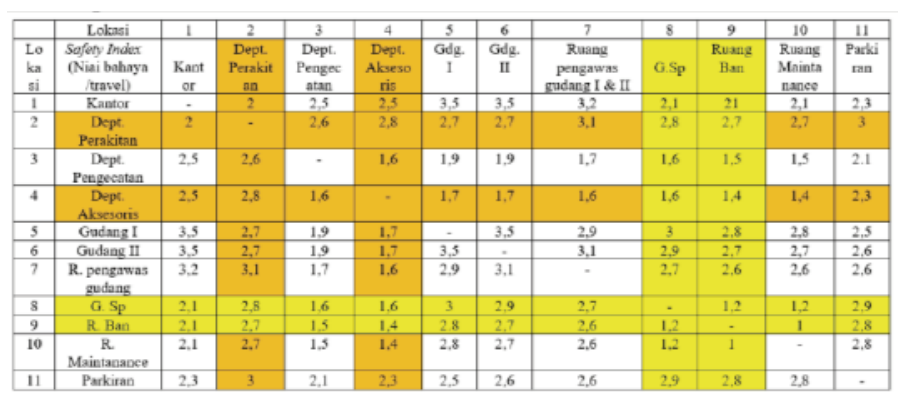

Tabel 4.26 Hasil Skenario 3 SI $\left(s_{i j} * F_{i j}\right)$

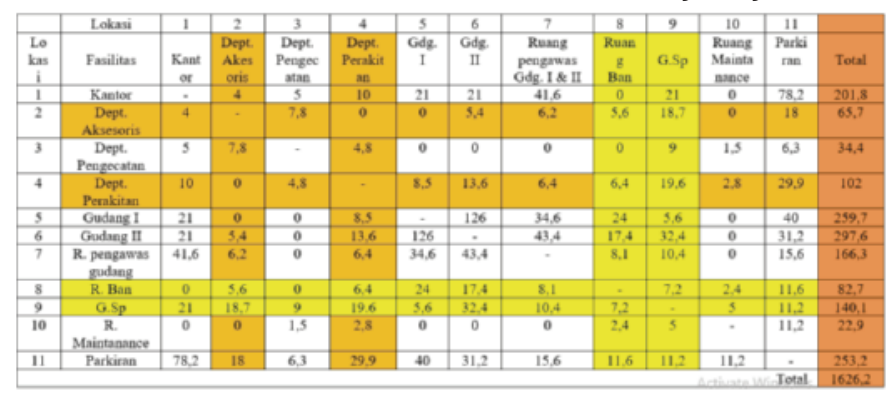

Pada skenario 3 ini didapatkan nilai TD sebesar 44066 meter dan nilai SI sebesar 1626,4 .

- $\quad$ Skenario 4,

Pada skenario ini terjadi perubahan fasilitas dengan melakukan pertukaran lokasi Departemen Pengecatan dengan Departemen Aksesoris dan juga pertukaran lokasi antara Ruang Ban dan Ruang Maintenance.

Tabel 4.27 Frekuensi antar fasilitas $\left(F_{i j}\right)$ Skenario 4

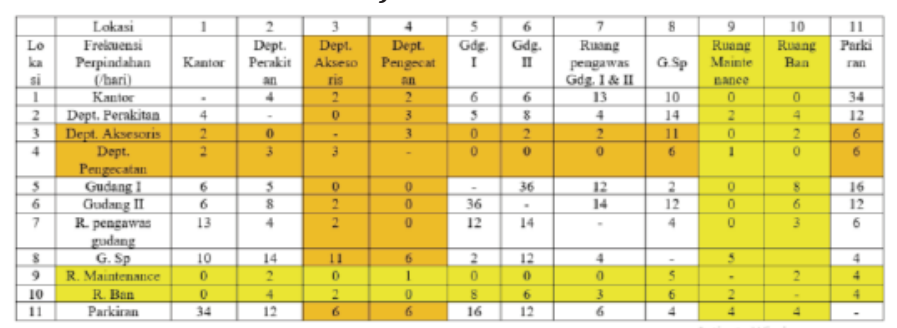


Tabel 4.28 Jarak antar fasilitas $\left(\boldsymbol{d}_{i j}\right)$ Skenario 4

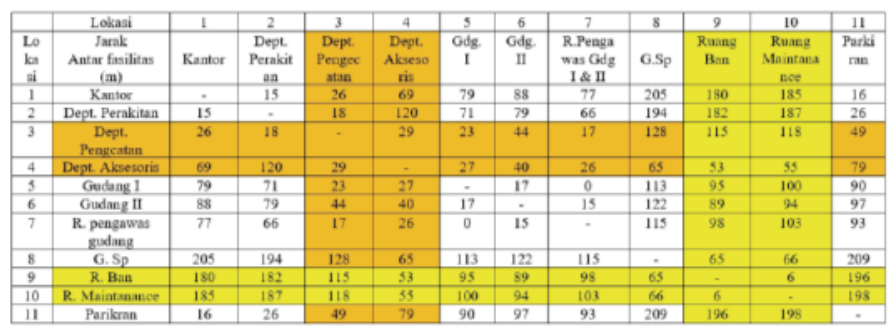

Tabel 4.29 Hasil Skenario 4 TD

$$
\left(\boldsymbol{d}_{i j} * \boldsymbol{F}_{\boldsymbol{i j}}\right)
$$

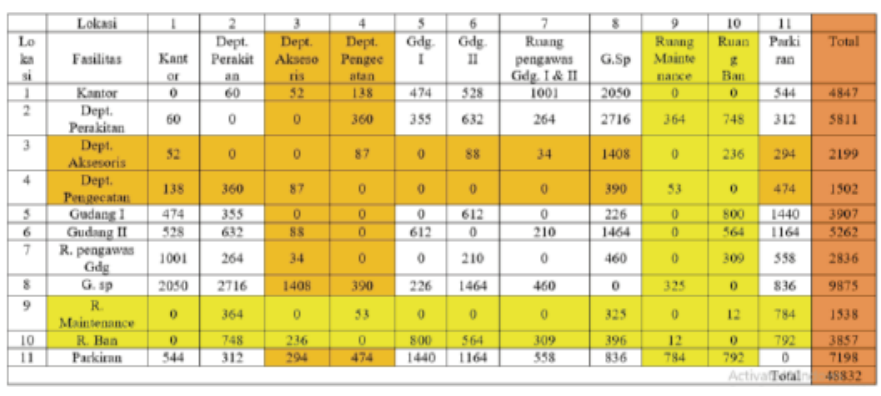

Tabel 4.30 Safety Index antar fasilitas $\left(s_{i j}\right)$ Skenario 4

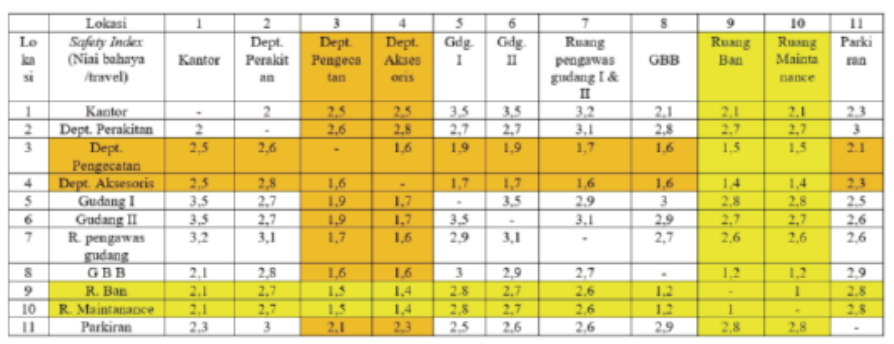

Tabel 4.31 Hasil Skenario 4 SI $\left(s_{i j} * F_{i j}\right)$

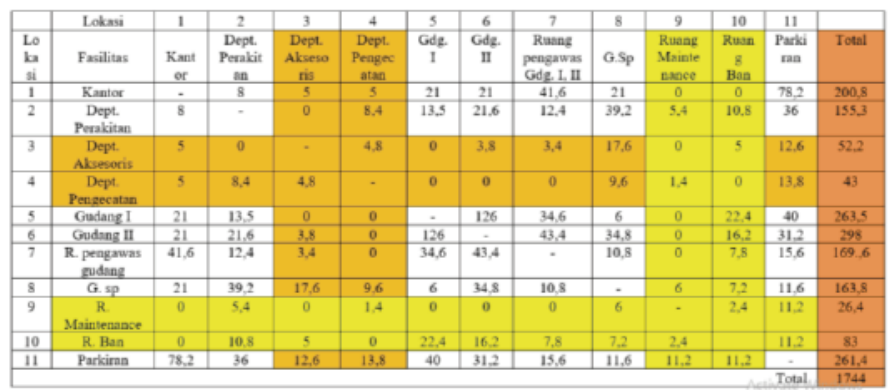

Pada skenario ini didapatkan nilai TD sebesar 48832 dan nilai SI sebesar 1744.

Setelah mendapatkan semua hasil TD dan SI dari setiap skenario maka dapat diketahui nilai perubahan yang terjadi tiap skenario. Bisa dilihat ditabel berikut ini.

Tabel 4.31 Hasil Seluruh Skenario

\begin{tabular}{|c|c|c|}
\hline Skenario & $\begin{array}{c}\text { Travel Distance } \\
\text { (TD) }\end{array}$ & $\begin{array}{c}\text { Safety Index } \\
\text { (SI) }\end{array}$ \\
\hline 0 & 47786 & 1649,9 \\
(Eksisting) & 45606 & 1682,6 \\
\hline 1 & 45398 & 1590,5 \\
\hline 2 & 44066 & 1626,4 \\
\hline 3 & 48832 & 1744 \\
\hline 4 & & \\
\hline
\end{tabular}

\subsubsection{Simulasi Arena}

Dari hasil yang didapatkan dari seluruh skenario untuk mencari nilai TD dan SI. Maka peneliti akan mengambil skenario yang paling optimal yaitu skenario dengan nilai TD dan SI terkecil adalah skenario 3 yang akan digunakan sebagai layout usulan. Layout usulan akan dibandingkan dengan layout awal dengan menggunakan simulasi arena. Pada simulasi ini yang dijadikan perbandingan adalah waktu dari perpindahan antar fasilitas awal dan waktu perpindahan antar fasilitas usulan (skenario 3). Berikut adalah tabel waktu perpindahan tiap produk antar fasilitas. 
Tabel 4.32 Waktu Perpindahan Tiap

Produk antar Fasilitas (Awal)

\begin{tabular}{|c|c|c|c|c|}
\hline No & Lokasi & 1 & 2 & 3 \\
\hline $\begin{array}{c}\text { Lo } \\
\text { kas } \\
\mathrm{i}\end{array}$ & $\begin{array}{c}\text { Waktu } \\
\text { Perpindahan } \\
(\text { menit/1x) }\end{array}$ & $\begin{array}{c}\text { Dept. } \\
\text { Perakita } \\
\mathrm{n}\end{array}$ & $\begin{array}{c}\text { Dept. } \\
\text { Pengeca } \\
\text { tan }\end{array}$ & $\begin{array}{c}\text { Dept. } \\
\text { Aksesoris }\end{array}$ \\
\hline 1 & $\begin{array}{c}\text { Dept. } \\
\text { Perakitan }\end{array}$ & - & 25 & 35 \\
\hline 2 & $\begin{array}{c}\text { Dept. } \\
\text { Pengecatan }\end{array}$ & 25 & - & 18 \\
\hline 3 & $\begin{array}{c}\text { Dept. } \\
\text { Aksesoris }\end{array}$ & 35 & 18 & - \\
\hline
\end{tabular}

Untuk waktu perpindahan tiap produk antar fasilitas, pada skenario 3 terjadi pertukaran antar Departemen Perakitan dan Departemen Aksesoris. Berikut adalah lama waktu perpindahan tiap produk antar fasilitas usulan.

Tabel 4.33 Waktu Perpindahan Tiap Produk antar Fasilitas (Usulan)

\begin{tabular}{|c|c|c|c|c|}
\hline No & Lokasi & 1 & 2 & 3 \\
\hline $\begin{array}{c}\text { Lo } \\
\text { kas } \\
\mathrm{i}\end{array}$ & $\begin{array}{c}\text { Waktu } \\
\text { Perpindaha } \\
\mathrm{n} \\
\text { (menit/1x) }\end{array}$ & $\begin{array}{c}\text { Dept. } \\
\text { Aksesoris }\end{array}$ & $\begin{array}{c}\text { Dept. } \\
\text { Pengecata } \\
\mathrm{n}\end{array}$ & $\begin{array}{c}\text { Dept. } \\
\text { Perakitan }\end{array}$ \\
\hline 1 & $\begin{array}{c}\text { Dept. } \\
\text { Aksesoris }\end{array}$ & - & 25 & 35 \\
\hline 2 & $\begin{array}{c}\text { Dept. } \\
\text { Pengecatan }\end{array}$ & 25 & - & 18 \\
\hline 3 & $\begin{array}{c}\text { Dept. } \\
\text { Perakitan }\end{array}$ & 35 & 18 & - \\
\hline
\end{tabular}

Begitu juga dengan skenario usulan, telah dilakukan pemodelan menggunakan simulasi Arena dengan terjadi pertukaran lokasi antara Departemen Perakitan dan Departemen Aksesoris. Simulasi dijalankan dengan waktu yang sama yaitu 30 hari proses produksi dengan jumlah replicant 10. Setelah itu didapatkan hasil dari yang bisa dilihat pada Lampiran 2. Berikut adalah gambar bentuk model dari simulasi yang dijalankan.

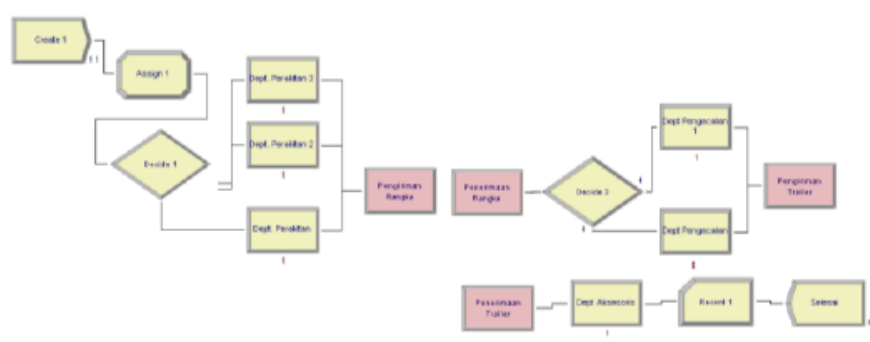

Gambar 4.2 Model Simulasi Arena

Setelah dilakukan maka hasil dari skenario tersebut akan dilakukan untuk uji validitas. Berikut adalah tabel uji validitas dari skenario awal dan usulan.

Tabel 4.34 Uji Validitas Skenario Awal

\begin{tabular}{|c|c|c|c|}
\hline No & Real & Simulasi Awal & Total \\
\hline 1 & 5 & 5 & 10 \\
\hline 2 & 6 & 5 & 11 \\
\hline 3 & 5 & 6 & 11 \\
\hline 4 & 5 & 3 & 8 \\
\hline 5 & 5 & 5 & 10 \\
\hline 6 & 6 & 6 & 12 \\
\hline 7 & 5 & 4 & 9 \\
\hline 8 & 6 & 5 & 11 \\
\hline 9 & 6 & 8 & 14 \\
\hline 10 & 3 & 6 & 9 \\
\hline & 0,63418 & 0,847231655 & \\
\hline Status : & Diterima & Diterima & \\
\hline
\end{tabular}


Tabel 4.35 Uji Validitas Skenario

Usulan

\begin{tabular}{|c|c|c|c|}
\hline No & Real & $\begin{array}{c}\text { Simulasi } \\
\text { Usulan }\end{array}$ & Total \\
\hline 1 & 5 & 5 & 10 \\
\hline 2 & 6 & 5 & 11 \\
\hline 3 & 5 & 6 & 11 \\
\hline 4 & 5 & 3 & 8 \\
\hline 5 & 5 & 5 & 10 \\
\hline 6 & 6 & 6 & 12 \\
\hline 7 & 5 & 4 & 9 \\
\hline 8 & 6 & 5 & 11 \\
\hline 9 & 6 & 8 & 14 \\
\hline 10 & 3 & 6 & 9 \\
\hline & 0,63418 & 0,847231655 & \\
\hline Status : & Diterima & Diterima & \\
\hline
\end{tabular}

Dari simulasi skenario awal dan skenario usulan didapatkan bahwa hasil jumlah produk dari setiap replicant didapatkan hasil yang sama dari kedua skenario. Jadi pertukaran fasilitas pada skenario usulan tidak mempengaruhi jumlah produk dalam jangka waktu 30 hari.

\subsection{Hasil Pengolahan Data}

\subsubsection{Analisis Multi-Objective Function}

Dari hasil pengolahan data pada bab sebelumnya peneliti telah membuat 5 skenario yang menampilkan hasil dari beberapa rencana perancangan pada layout persuhaaan dengan melakukan perihitugan pada travel distance dan safety index. Selanjutnya peneliti akan membandingan setiap skenario mulai dari skenario 0 (kondisi awal) sampai dengan skenario 4 apakah semakin naik atau menurun. Berikut adalah tabel perbandingan dari semua skenario.
Tabel 4.36 Tabel Perbandingan Antar Skenario

\begin{tabular}{|c|c|c|}
\hline Skenario & $\begin{array}{c}\text { Nilai Travel } \\
\text { Distance (TD) } \\
\mathbf{4 7 7 8 6} \text { (awal) }\end{array}$ & $\begin{array}{c}\text { Nilai Safety } \\
\text { Index (SI) } \\
\mathbf{1 6 4 9 , 9} \text { (awal) }\end{array}$ \\
\hline 1 & $45606 \mathrm{~m}$ & 1682,6 \\
\hline 2 & $45398 \mathrm{~m}$ & 1590,5 \\
\hline 3 & $44066 \mathrm{~m}$ & 1626,4 \\
\hline 4 & $48832 \mathrm{~m}$ & 1744 \\
\hline
\end{tabular}

Setelah dilakukan perbandingan maka selanjutya peneliti membuat Diagram untuk melihat keseluruhan dari skenario sebagi berikut.

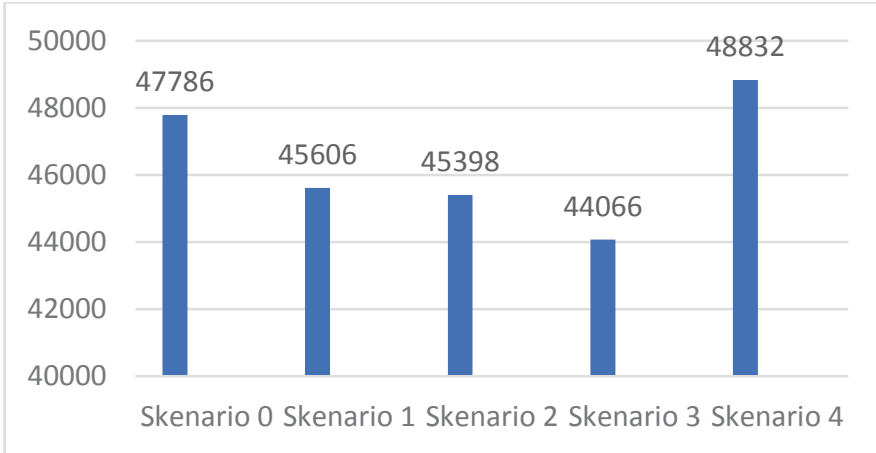

Gambar 4.3 Diagram Skenario TD

Dari diagram diatas bisa dilihat bahwa skenario 3 mempunyai nilai td yang paling rendah dengan patokan skenario nol sebagai kondisi awal perushaan, hal ini membuktikan bahwa peggunaan skenario 3 akan berpengaruh untuk mengurangi jarak total perpindahan material. Kemudian diikuti dengan nilai TD terendah yaitu pada seknario 2 setelah itu dikikuti skenario 1. Namun pada skenario 4 terjadi penigkatan melebihi skenario 0 sebagai patokan 


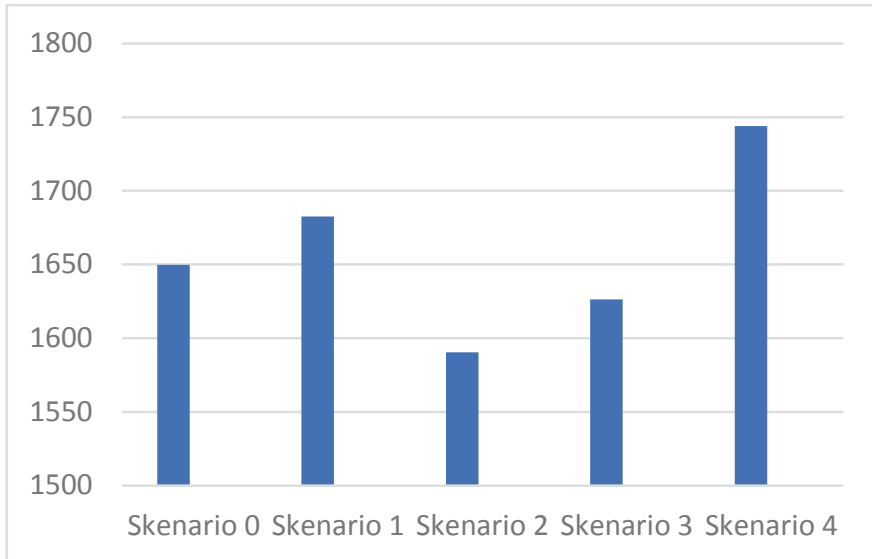

Gambar 4.4 Diargam Skenario SI

Pada diagram skenario SI bisa dilihat bahwa skenario 2 yang mempunyai nilaii SI terendah dengan skenario 0 sebagai patokan setelah itu di susul oleh skenario 3 sebagai nilai terendah setelah sknario 2. Hanya ada 2 skenario yang dapat mengurai SI. Pada skenario 1 dan 4 terjadi kenaikan melebihin skenario 0 , hal ini membuktikan bahwa penggunan usulan pada skenario 1 dan 4 akan meningkatkan SI. Berikut adalah gambar layout skenario 0 (awal) dan gambar layout skenario 3(usulan).

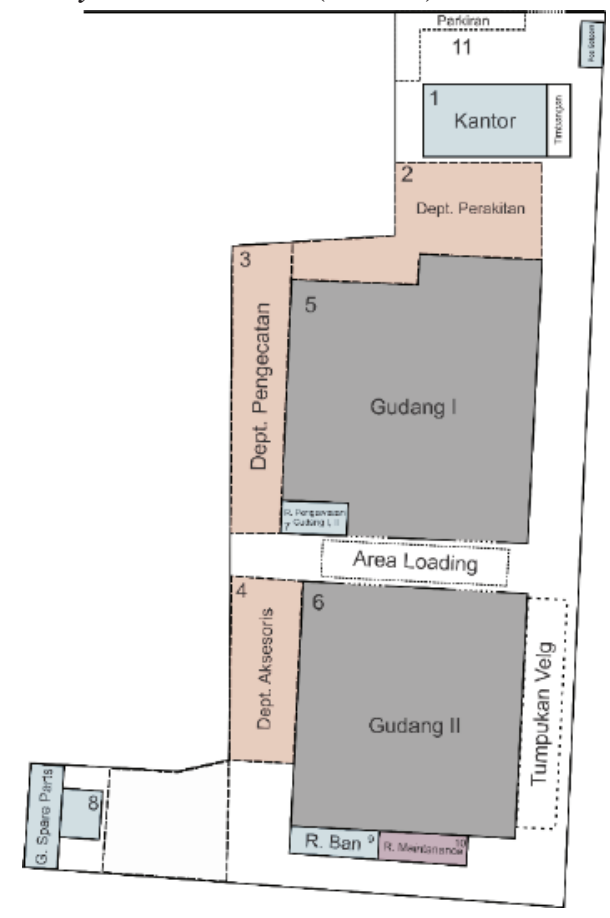

Gambar 4.5 Layout Skenario 0 (Awal)

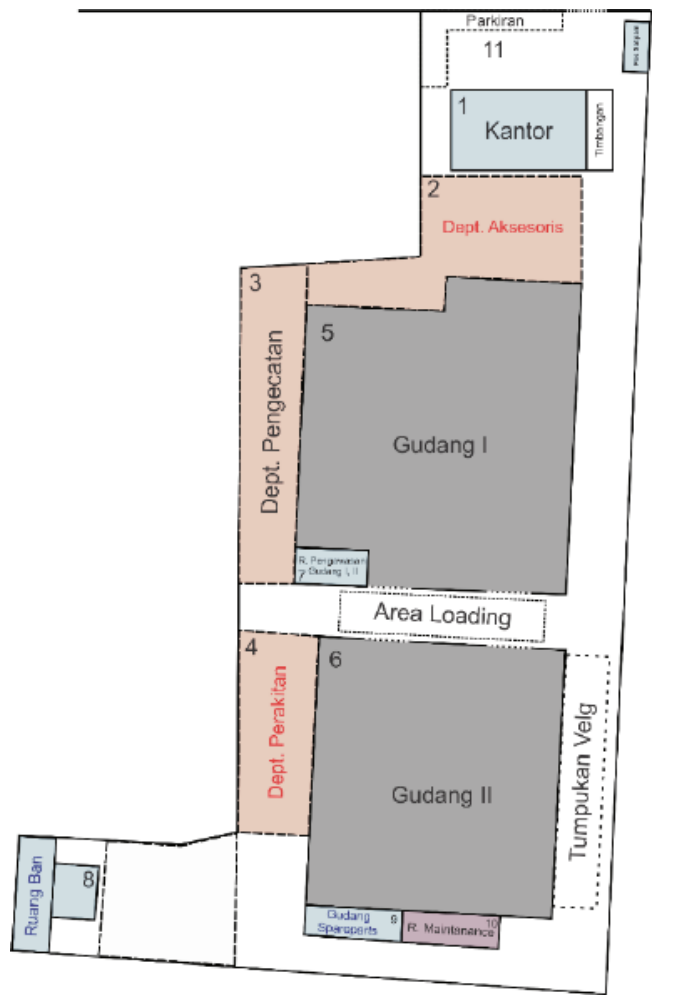

Gambar 4.5 Layout Skenario 3 (Usulan)

\subsubsection{Simulasi Arena}

Dari hasil simulasi yang dilakukan dengan waktu proses produksi selama 30 hari dengan jumlah replicant 10 didapatkan hasil dari layout awal (Lampiran 1) dan usulan (Lampiran 2) bahwa tidak ada terjadi perubahan pada jumlah produksi, walaupun telah terjadi pertukaran pada Departemen Perakitan dengan Deparetemen Aksesoris. Berikut adalah tabel simulasi skenario awal dan skenario usulan. 
Tabel 4.37 Hasil Simulasi Arena

\begin{tabular}{|c|c|c|c|}
\hline \multicolumn{2}{|c|}{ Replicant } & Simulasi & Simulasi \\
\hline 1 & \multirow{10}{*}{ 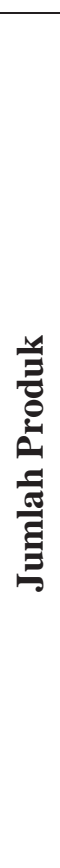 } & 5 & 5 \\
\hline 2 & & 5 & 5 \\
\hline 3 & & 6 & 6 \\
\hline 4 & & 3 & 3 \\
\hline 5 & & 5 & 5 \\
\hline 6 & & 6 & 6 \\
\hline 7 & & 4 & 4 \\
\hline 8 & & 5 & 5 \\
\hline 9 & & 8 & 8 \\
\hline 10 & & 6 & 6 \\
\hline
\end{tabular}

\section{KESIMPULAN}

\subsection{Kesimpulan}

Dari hasil perhitungan dan juga analisis dari MOF dapat disimpulkan bahwa dari perhitungan travel distance keseluruhan skenario dapat dilihat bahwa terjadi penurunan dan kenaikan dari hasil skenario. Namun tujuan untuk perhitungan MOF ini adalah untuk meminimalkan travel distance dan safety index maka semakin menurun nilai dari skenario tersebut maka semakin optimal pula skenario tersebut untuk diterapkan sebagai usulan dalam perancangan tata letak fasilitas. Ada beberapa kesimpulan yang bisa dijabarkan sebagai berikut :

a) Pada perhitungan skenario 0 yaitu pada kondisi awal dimana belum terjadi perusahaan, didapatkan bahwa skenario tersebut memiliki nial TD sebesar 47786 meter dan SI sebesar 1649,9. b) Selanjutnya pada skenario 1 terdapat penurunan nilai meter menjadi 45606 meter dan kenaikan pada nilai SI sebesar 32,7 menjadi 1682,6.

c) Pada skenario 2 terdapat penurunan nilai TD sehingga pada nilai TD skenario 2 menajdi 45398 dan juga terjadi penurunan nilai SI sebesar 56,4 sehingga nilai SI menjadi 1590,5 .

d) Pada skenario 3 terjadi penurunan pada nilai TD meter sehingga nilai TD menjadi 44066 meter dan juga terjadi penurunan pada nilai SI sebesar 23,5 sehingga nilai SI menjadi 1626,4.

e) Pada skenario 4 terjadi kenaikan pada nilai TD sehingga nilai TD menjadi 48832 dan juga terjadi kenaikan nilai SI sebesar 94,1 sehingga nilai SI menjadi 1744.

Dari penjabaran diatas dapat dilihat bahwa skenario 3 adalah skenario yang layak untuk dijadikan usulan untuk perusahaan karena pada nilai TD skanrio 3 adalah yang mempunyai nilai terendah walaupun pada nilai SI bukanlah nilai terendah namun tetatp terjadi penurun di skenario 3.

Pada Simulasi Arena didapatkan hasil jumlah produk per replicant yang sama antara simulasi layout awal dan simulasi layout usulan. Jadi bisa dikatakan bahwa perubahan yang terjadi pada skenario usulan dengan melakukan pertukara antara Departemen Perakitan dan Departemen Akesoris tidak merubah jumlah produk (dengan simulasi selama 30 hari proses produksi). Pada penelitian ini dengan menggunakan MOF dan juga simulasi Arena bisa mengusulkan layout yang hanya mengubah total jarak perpindahan dan tingkat keamanan namun untuk meningkatkan produktivitas belum bisa ditingkatkan pada layout usulan dalam penelitian ini.

\subsection{Saran}

Pada penelitian ini, peneliti memberikan saran kepada para peneliti selanjutnya yang akan 
meneliti tata letak fasilitas dengan menggunakan metode Multi-Objective Function perlu diketahui bahwa MOF merupakan metode yang bersifat kuantitatif sehingga hasil yang didapatkan menjadi lebih jelas dengan adanya perbandingan data berupa angka. Namun, pada penelitian ini terdapat kekurangan yaitu dalam pembuatan sekanrio pada penentuan fasilitas yang akan diubah pada setiap skenario sehingga metode MOF perlu digandengkan dengan metode kualitatif untuk menentukan perubahan-peruahan yang terjadi pada setiap skenario. Jika peneliti selanjutnya menggunakan simulasi makan akan terjadi penambahan pengumpulan data. Sehingga pembuatan simulasi tidak hanya mengambil data dari perhitungan MOF namun mempunyai pengumpulan data sendiri mengenai waktu.

\section{DAFTAR PUSTAKA}

Andre, O. (2016), Simulasi Model Sistem Kerja Pada Departemen Injection Untuk Meminimasi Waktu Work-In-Prcess.

Enriko S , Sugiyarto , Sunarmasto (2018), Optimalisasi Tata Letak Fasilitas Pada Proyek Pembangunan Gedung Sudirman Suite Jakarta Menggunakan Metode Multi Objectives Function.

Erni, N., Lamto Widodo, Poala, Y. (2017), Usulan Perancangan Ulang Tata Letak Pabrik Pada Pt. Xyz.

Lestari, S. (2014), Analisa Tata Letak Pabrik Untuk Meminimalisasi Material Handling Pada Pabrik Sheet Metal Dengan Software Promodel.

Nur, I., Hadi, F. (2015), Model Optimisasi Tata Letak Pelabuhan Curah Kering dengan Pendekatan Simulasi Diskrit: Studi Kasus Pelabuhan Khusus PT Petrokimia Gresik

Pradana, E., Nurcahyo, B. (2014), Analisis Tata Letak Fasilitas Proyek Menggunakan Activity Relationship Chart dan MultiObjectives Function pada Proyek
Pembangunan Apartemen De Papilio Surabaya.

Pranarka, D. \& Joko, T. (2012), Optimasi (EQUAL) Site Layout Menggunakan Multi-Objective Function pada Proyek A.

Purnomo, H. (2004), Perencanaan \& Perancangan Fasilitas, Graha Ilmu.

Wignjosoebroto, S. (2003), Pengantar Teknik \& Manajemen Industri, Guna Widya. 